\title{
Comparative study of lung function in Iranian factory workers exposed to silica dust
}

\author{
A.R. Bahrami' and H. Mahjub'
}

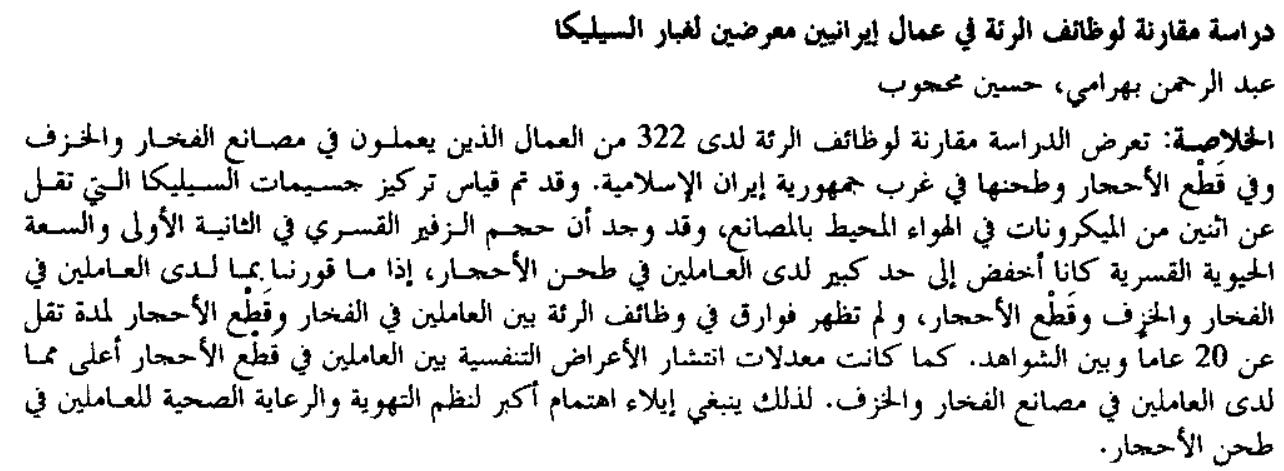

ABSTRACT The study compared lung function among 322 workers in pottery, ceramic, stone-cutter and stone-grinder factories in the west of the Istamic Republic of Iran. Concentrations of silica particles $<2 \mu \mathrm{m}$ were measured in the ambient air of factories. Forced expiratory volume in 1 second (FEV, and forced vital capacity (FVC) were significantly lower in stone-grinders compared with pottery, ceramic or stone-cutter workers and a control group. No difference in lung function was found in pottery and stone-cutter workers with less than 20 years occupation compared with controls. The prevatence of respiratory symptoms in stone-grinders was higher than other workers. The concentration of silica particles of stone-grinder factories was 40-110 times higher than in ceramic and potteries factories. More attention is needed to ventilation systems and health care of stone-grinders.

\begin{abstract}
Etude comparative de la fonction pulmonaire chez des ouvriers iraniens exposés a la poussière de silice

RESUME L'étude a comparé la fonction pulmonaire de 322 ouvriers dans des ateliers de poterie, de céramique, de coupe et de taille de pierre dans l'ouest de la République islamique d'Iran. Des concentrations de particules de silice inférieures à $2 \mu \mathrm{m}$ ont été mesurées dans lair ambiant des ateliers. Le volume expiratoire maximum seconde (VEMS) et la capacité vitale (CV) étaient significativement plus faibles chez. les tailleurs de pierre que chez les potiers. les ouvriers de la céramique ou les coupeurs de pierre et dans un groupe témoin. Aucune différence n'a été trouvée pour la fonction pulmonaire chez les potiers et les tailleurs de pierre ayant moins de 20 ans de métier par rapport aux témoins. La prévalence des symptômes respiratoires chez les tailleurs de pierre était plus élevée que chez les autres ouvriers. La concentration de particules de silice dans les ateliers de taille de pierre était de 40 à 110 fois plus élevée que dans les ateliers de céramique et de poterie. Une plus grande attention doit être accordée aux systèmes de ventilation et à la protection de la santé des tailleurs de pierre.
\end{abstract}

'Department of Occupational Health; 'Department of Biostatistics, Faculty of Health, Hamadan University of Medical Science, Hamadan, Islamic Republic of Iran.

Received: 02/05/02; accepted: $10112 / 02$

$$
\text { المجلة الصحية لشرق المتو سط، منظمة الصحة العالمية، المجلد الثاسع، العدد ب، ب... }
$$




\section{Introduction}

Inhalation of silica particles injures lung tissue, leading to silicosis through an immunological mechanism involving alveolar macrophages [ $1-3]$. The risk of developing silicosis is well known among pottery and ceramic workers and stone cutters and stone grinders, because of the presence of respirable crystalline silica particles in the work environment [4-7]. Prowse et al. [4] reported that among women pottery workers, the average decline of $\mathrm{FEV}_{\text {, [forced }}$ expiratory volume in 1 second] in those with simple silicosis was $18 \mathrm{~mL}$ per year and for those with conglomerate disease 38 $\mathrm{mL}$ per year. Definite impairment of lung function in slate workers with simple silicosis was reported by Glover et al. [6], suggesting that the degree of respiratory impairment may depend on the type of exposure causing the silicosis.

Earlier studies of the exposure of workers to stone particles have depicted benign pneumoconioses in the form of radiological changes and obstructive impairment of lung functions [8]. Although some studies report that lung function impairment is related to inhalation of respirable silica $[1,9,10]$ there is little data on lung function comparing different occupations. Furthermore, little is known about the health of workers exposed to silica in the Islamic Republic of Iran.

Lalejin town, in Hamadan state in the West of the Islamic Republic of Iran, is a centre for pottery and ceramic workers. The people in this area have been employed in pottery making for a long time throughout history. The Azandarian area, a suburb of Hamadan city is a base for stone-cutter and stone-grinder factories. The stonecutter factories produce stone that is used in construction work and stone-grinders produce silica powders for glass factories throughout the country.

The aim of this study was to compare lung function and symptoms among men exposed to silica dust in different types of factories in Hamadan state compared with a control group.

\section{Methods}

The study was carried out on a sample of men exposed to silica dust in 4 occupational groups in Hamadan state: ceramic, pottery, stone-grinder and stone-cutter workers. The study group of 322 was selected from 2014 workers at the factories by simple random sampling. A control group of 133 non-exposed men working in office-based businesses were selected from the same state. The control group was matched with the study group based on age, smoking status and area of residence.

Age, height and weight were recorded for each member of the study and control groups in order to calibrate the spirometer. A detailed questionnaire was completed for study and control participants, providing information about duration of exposure to silica dust (years), smoking history and clinical symptoms.

Measurements of lung function were made using a digital portable spirometer (model ST300, Fukada). All tests were performed in the sitting position and the subject was asked to exhale into the spirometer as forcibly as possible after maximum inspiration [11]. Each test was repeated 3 times and the highest reading was taken for calculation. The following parameters recorded: forced expiratory volume (FEV), forced expiratory volume in 1 second $\left(\mathrm{FEV}_{1}\right)$ forced vital capacity

المجلة الصحية لشترق المتوسط، منظمة الصحة العالمية، المجلد التاسع، العلد r، بr. 
(FVC), vital capacity (VC) and predicted vital capacity (PVC) [1/]. The FEV,FVC and $\mathrm{FVC} / \mathrm{PVC}$ ratios were calculated as percentages. Means and standard deviations (s) were calculated.

To measure the concentrations of silica particles in the ambient air of the factories an air sampler pump (model 224-30, SKC) connected to a mini-cyclone (SKC) and glass filters were used. Calibration and adjustment of the sampling flow rates was achieved using a flow meter connected between the sampler and the pump. The mini-cyclone traps all particles with diameter $>2 \mu \mathrm{m}$ and the filter collects particles $<2 \mu \mathrm{m}[/ 2]$. The total concentration of particles $>2 \mu \mathrm{m}$ and the concentrations of respirable particles $<2 \mu \mathrm{m}$ (i.e. the component of inhalable dust that reaches the gas exchange region of the lung, the alveoli) were measured from the increased mass of the filter weighed on an electrical balance.

Data analysis was made using SPSS version 9.0 and Epi-Info version 6. For comparison of pulmonary signs with control groups, chi-squared and Fisher exact tests were used. Unpaired $t$-tests were used to compare pulmonary parameters between occupational groups and between smokers and non-smokers.

\section{Results}

The background data showed no significant differences between the study and control groups with regard to age, smoking status or residence.

Table 1 shows the duration of employment, smoking status and presence of various signs and symptoms among the 4 different types of factory worker. There were similar proportions of smokers in the different worker groups: ceramic $(28.9 \%)$, pottery $(29.3 \%)$, stone-cutting $(33.9 \%)$ stone-grinding $(32.4 \%)$ and controls $(30.2 \%)$. Although there were some differences in symptoms between different types of factory worker, these were mostly not significant. Respiratory symptoms were reported by a higher proportion of workers in stone-grinder factories than other workers. Significantly more stonegrinders than stone-cutters had chronic cough $(P<0.05)$. Also significantly more stone-grinders reported acute phlegm than pottery workers $(P<0.05)$ and stonecutters $(P<0.05)$. Significantly more stone-grinders reported acute phlegm, chronic phlegm, chest tightness and chest pain than the controls $(P<0.05)$. For most of the symptom categories, more workers in pottery, ceramic and stone-cutting factories reported symptoms than the control group but the differences were not statically significant.

Table 2 shows the mean values of the lung function tests in the 4 occupancy groups according to duration of employment. There were no significant differences in lung function among ceramic, pottery and stone-cutter workers with duration of employment lower than 20 years compared with the control group. However, a significant difference was seen in the FEV, of pottery, ceramic and stone-cutter workers working for more than 20 years compared with the controls $(P<0.05)$. A significant difference was seen in the mean FEV, of pottery, ceramic and stone-cutter workers with 11-20 years duration employment compared with the stone-grinder $(P<0.05)$ and also for employment less than 10 years a significant difference was seen between ceramic workers and stone-grinder workers $(P<0.05)$. There was a significant difference between the FVC of stone-

$$
\text { المجلة الصحية لمثرق المتوسط، منظمة الصححة العالمية، المجلد التاسع، العدد ب، r.. }
$$


Table 1 Duration of employment, smoking status and prevalence of respiratory symptoms, comparing groups of workers from different types of factory and a control group

\begin{tabular}{|c|c|c|c|c|c|c|c|c|c|c|}
\hline \multirow[t]{2}{*}{ Variable } & \multicolumn{2}{|c|}{$\begin{array}{l}\text { Pottery } \\
(n=180)\end{array}$} & \multicolumn{2}{|c|}{$\begin{array}{l}\text { Ceramic } \\
(n=41)\end{array}$} & \multicolumn{2}{|c|}{$\begin{array}{l}\text { Stone- } \\
\text { cutting } \\
(n=67)\end{array}$} & \multicolumn{2}{|c|}{$\begin{array}{l}\text { Stone- } \\
\text { grinding } \\
(n=34)\end{array}$} & \multicolumn{2}{|c|}{$\begin{array}{l}\text { Controls } \\
(n=133)\end{array}$} \\
\hline & No. & $\%$ & No. & $\%$ & No. & $\%$ & No. & $\%$ & No. & $\%$ \\
\hline \multicolumn{11}{|l|}{ Employment duration (years) } \\
\hline $0-10$ & 108 & 60.0 & 25 & 61.0 & 37 & 56.9 & 26 & 76.5 & 77 & 61.1 \\
\hline $11-20$ & 44 & 24.4 & 10 & 24.4 & 18 & 27.7 & 8 & 23.5 & 34 & 27.0 \\
\hline $21+$ & 28 & 15.6 & 6 & 14.6 & 12 & 18.5 & 0 & 0 & 22 & 17.5 \\
\hline \multicolumn{11}{|l|}{ Smoking status } \\
\hline Smokers & 52 & 28.9 & 12 & 29.3 & 22 & 33.9 & 11 & 32.4 & 38 & 30.2 \\
\hline Non-smokers & 128 & 71.1 & 29 & 70.7 & 43 & 66.1 & 23 & 67.6 & 88 & 69.8 \\
\hline \multicolumn{11}{|l|}{ Symptoms } \\
\hline Acute cough ${ }^{a}$ & 35 & 19.4 & 10 & 24.4 & 11 & 16.9 & 13 & 38.2 & 19 & 15.1 \\
\hline Chronic cough $^{\mathrm{b}}$ & 17 & 9.4 & 5 & 12.2 & 6 & 9.2 & 7 & 20.6 & 13 & 10.3 \\
\hline Acute phlegm ${ }^{a}$ & 11 & 6.1 & 6 & 14.6 & 4 & 6.2 & 7 & $20.6^{\star}$ & 7 & 5.6 \\
\hline Chronic phlegm ${ }^{\mathrm{b}}$ & 9 & 5.0 & 2 & 4.9 & 7 & 10.8 & 6 & $17.7^{*}$ & 6 & 4.8 \\
\hline Chest tightness & 17 & 9.4 & 5 & 12.2 & 5 & 7.7 & 7 & $20.6^{*}$ & 10 & 7.9 \\
\hline Wheeze apart from colds & 12 & 6.7 & 5 & 12.2 & 4 & 6.2 & 5 & 14.7 & 10 & 7.9 \\
\hline Chest pain & 11 & 6.1 & 2 & 4.9 & 2 & 3.1 & 8 & $23.5^{*}$ & 6 & 4.8 \\
\hline
\end{tabular}

$p<0.05$ compared with control group.

$\mathrm{n}=$ number of subjects.

${ }^{a}$ Acute coughiphlegm present for a few days or weeks.

${ }^{\circ}$ Chronic coughiphlegm present for months or years.

grinders with more than 10 years occupation and the control group $(P<0.05)$. No stone-grinder workers had a duration of employment more than 20 years.

Table 3 compares pulmonary parameters for smokers and non-smokers among the stone-cutters and stone-grinders compared with the control group. There was a significant difference for $\mathrm{FEV}_{1}$ and FVC/PVC in stone-grinders compared with the control group $(P<0.05)$ but no significant difference was seen in these parameters comparing smokers and non-smokers in the stone-grinder and stone-cutter groups. Although in general, the lung function results for the stone-grinder and stonecutter workers were comparable, there were some exceptions. There was a significant difference between stone-grinders (smoking and non-smoking) and the control group for $\mathrm{FEV}_{1}(P<0.05)$.

Table 4 shows the mean concentrations of respirable particles in the ambient air at the different factories. The concentrations of total particles in the stone-grinder environment was 12 to 92 times higher than for pottery, ceramic or stone-cutter workers.

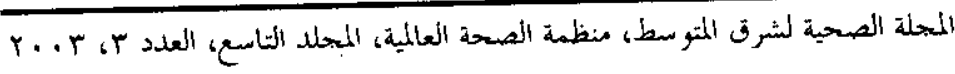


Table 2 Duration of employment and lung function, comparing groups of workers from different types of factory and a control group

\begin{tabular}{|c|c|c|c|c|c|c|c|c|c|c|}
\hline \multirow[t]{2}{*}{$\begin{array}{l}\text { Employment duration } \\
\text { and lung function }\end{array}$} & \multicolumn{2}{|c|}{ Pottery } & \multicolumn{2}{|c|}{ Ceramic } & \multicolumn{2}{|c|}{$\begin{array}{l}\text { Stone- } \\
\text { cutting }\end{array}$} & \multicolumn{2}{|c|}{$\begin{array}{l}\text { Stone- } \\
\text { grinding }\end{array}$} & \multicolumn{2}{|c|}{ Controls } \\
\hline & Mean & (s) & Mean & (s) & Mean & (s) & Mean & (s) & Mean & (s) \\
\hline \multicolumn{11}{|l|}{$0-10$ years } \\
\hline $\mathrm{VC}(\mathrm{L})$ & 4.18 & $(0.48)$ & 4.20 & $(0.48)$ & 4.10 & $(0.65)$ & 4.11 & $(0.75)$ & 4.20 & $(0.60)$ \\
\hline FVC (L) & 3.91 & $(0.43)$ & 4.12 & $(0.42)$ & 4.30 & $(0.50)$ & 3.90 & $(0.32)$ & 4.27 & (0.39) \\
\hline $\mathrm{FEV}_{1}(\mathrm{~L})$ & 3.64 & $(0.47)$ & 3.76 & $(0.38)$ & 3.66 & $(0.37)$ & 3.52 & $(0.34)^{\star}$ & 3.80 & $(0.42)$ \\
\hline FEV $/$ IFVC ratio (\%) & 92.89 & $(5.64)$ & 92.05 & $(6.12)$ & 85.11 & $(4.67)$ & 80.78 & $(6.12)$ & 85.42 & (5.93) \\
\hline FVCPVC ra & 83.93 & $(6.14)$ & 84.90 & $(5.18)$ & 89.76 & (5.71) & $76.33^{*}$ & $(5.09)$ & 89.84 & (7.11) \\
\hline \multicolumn{11}{|l|}{$11-20$ years } \\
\hline$V C(L)$ & 4.05 & $(0.39)$ & 3.98 & $(0.40)$ & 3.90 & $(0.59)$ & 3.85 & $(0.45)$ & 4.15 & (0.59) \\
\hline FVC (L) & 3.97 & $(0.39)$ & 3.88 & $(0.53)$ & 4.06 & $(0.49)$ & 3.71 & $(0.36)^{*}$ & 4.07 & $(0.34)$ \\
\hline FEV, (L) & 3.41 & $(0.45)$ & 3.39 & $(0.47)$ & 3.36 & $(0.39)$ & 2.88 & $(0.41)^{*}$ & 3.65 & $(0.32)$ \\
\hline FEV, IFVC & 85.04 & $(6.44)$ & 87.37 & $(5.32)$ & 74.66 & $(7.10)$ & 72.18 & $(6.01)$ & 83.41 & $(5.73)$ \\
\hline FVCIPVC, & 83.54 & $(5.86)$ & 83.49 & $(6.73)$ & 84.50 & $(5.18)$ & $75.17^{*}$ & $(7.23)$ & 91.67 & (4.19) \\
\hline \multicolumn{11}{|l|}{$21+$ years } \\
\hline$V C(L)$ & 3.18 & $(0.45)$ & 3.12 & $(0.44)$ & 3.65 & $(0.51)$ & - & - & 3.95 & $(0.34)$ \\
\hline FVC (L) & 3.50 & $(0.29)$ & 2.80 & $(0.31)^{*}$ & 3.17 & $(0.40)^{*}$ & - & - & 3.67 & $(0.43)$ \\
\hline $\mathrm{FEV}_{1}(\mathrm{~L})$ & 2.55 & $(0.33)^{*}$ & 2.48 & $(0.35)^{*}$ & 2.58 & $(0.42)^{*}$ & - & - & 3.19 & $(0.51)$ \\
\hline FEV, FVC & 76.51 & $(4.97)$ & 88.60 & $(4.18)$ & 81.38 & $\langle 7.12\rangle$ & - & - & 86.90 & $(4.80)$ \\
\hline FVC/PVC ratio (\%) & 79.20 & $(5.90)$ & $67.29^{\circ}$ & $(7.50)$ & $76.20^{*}$ & $(5.80)$ & - & - & 92.50 & (5.55 \\
\hline
\end{tabular}

"P $<0.05$ compared with control group.

$F V C=$ forced vital capacity; FEV $1=$ forced expiratory volume in 1 second; VC = forced vital capacity; PVC = predicted forced vital capacity.

$\mathrm{s}=$ standard deviation.

\section{Discussion}

The results of our study point toward an obstructive pattern of impairment of lung function among workers in stone-grinding factories in Hamadan. On comparing the 4 groups of workers for their lung function, stone-grinder workers had significantly lower FEV, and FVC values after 11-20 years of employment compared with pottery, ceramic and stone cutters, and stonegrinders employed less than 10 years were significantly impaired compared with ceramic workers.
The concentration of respirable particles in the stone-grinder environment was nearly 70 times higher than in the stonecutter factories. The method of stone cutting is based on the use of water during the processing. The water causes the particles to cohere together, increasing the weight and size of particles and thus lowering the concentration of smaller, respirable particles [7]. The stone-grinding process is completely dry; therefore, particles are emitted into the ambient air at concentrations $50-100$ times greater than 
Table 3 Lung function according to smoking status, comparing groups of workers from different types of factory and a control group

\begin{tabular}{|c|c|c|c|c|c|c|c|c|c|c|}
\hline \multirow[t]{2}{*}{$\begin{array}{l}\text { Lung function and } \\
\text { smoking status }\end{array}$} & \multicolumn{2}{|c|}{ Pottery } & \multicolumn{2}{|c|}{ Ceramic } & \multicolumn{2}{|c|}{$\begin{array}{l}\text { Stone- } \\
\text { cutting }\end{array}$} & \multicolumn{2}{|c|}{$\begin{array}{l}\text { Stone- } \\
\text { grinding }\end{array}$} & \multicolumn{2}{|c|}{ Controls } \\
\hline & Mean & (s) & Moan & (s) & Mean & (s) & Mean & (s) & Mean & (s) \\
\hline \multicolumn{11}{|l|}{$F V C(L)$} \\
\hline Smokers & 3.75 & $(0.49)$ & 3.83 & $(0.39)$ & 3.61 & $(0.33)$ & 3.65 & $(0.43)$ & 3.85 & $(0.44)$ \\
\hline Non-smokers & 4.10 & $(0.40)$ & 4.25 & $(0.41)$ & 4.01 & $(0.34)$ & 3.92 & $(0.45)$ & 4.20 & $(0.53)$ \\
\hline \multicolumn{11}{|l|}{$F E V_{1}(L)$} \\
\hline Smokers & 3.12 & $(0.32)$ & 3.42 & $(0.34)$ & 3.02 & $(0.33)$ & 2.75 & $(0.37)^{*}$ & 3.37 & $(0.45)$ \\
\hline Non-smokers & 3.44 & $(0.40)$ & 3.67 & $(0.45)$ & 3.32 & $(0.41)$ & 3.20 & $(0.34)^{*}$ & 3.60 & $(0.34)$ \\
\hline \multicolumn{11}{|l|}{ FEV,$F V C$ ratio (\%) } \\
\hline Smokers & 84.18 & $(5.17)$ & 83.27 & $(4.10)$ & 82.42 & $(6.13)$ & $74.18^{*}$ & $(5.32)$ & 84.53 & $(4.53)$ \\
\hline Non-smokers & 85.70 & $(5.39)$ & 84.12 & $(5.27)$ & 83.02 & $(6.70)$ & 79.14 & $(5.45)$ & 85.80 & $(4.13)$ \\
\hline
\end{tabular}

"P $<0.05$ compared with control group.

$F V C=$ forced vital capacity; FEV, = forced expiratory volume in 1 second.

$\mathrm{s}=$ standard deviation.

Table 4 Respirable and total dust concentrations in the ambient air in different types of factory

\begin{tabular}{|c|c|c|c|c|c|c|c|c|}
\hline \multirow[t]{2}{*}{ Particle type } & \multicolumn{2}{|c|}{$\begin{array}{l}\text { Pottery } \\
(n=12)\end{array}$} & \multicolumn{2}{|c|}{$\begin{array}{l}\text { Ceramic } \\
(n=12)\end{array}$} & \multicolumn{2}{|c|}{$\begin{array}{c}\text { Stone-cutting } \\
(n=16)\end{array}$} & \multicolumn{2}{|c|}{$\begin{array}{l}\text { Stone-grinding } \\
\quad(n=16)\end{array}$} \\
\hline & Mean & (s) & Mean & (s) & Mean & (s) & Mean & (s) \\
\hline Respirable dust $\left(\mathrm{mg} / \mathrm{m}^{3}\right.$ ) & 0.03 & $(0.002)$ & 0.08 & $(0.005)$ & 0.05 & $(0.004)$ & 3.33 & $(0.277)$ \\
\hline Total dust $\left(\mathrm{mg} / \mathrm{m}^{3}\right)$ & 0.18 & $(0.015)$ & 1.10 & $(0.084)$ & 1.40 & $(0.117)$ & 16.67 & (1.389) \\
\hline
\end{tabular}

$n=$ number of samples obtained in ambient air of work places.

$\mathrm{s}=$ standard deviation.

the threshold level $\left(0.05 \mathrm{mg} / \mathrm{m}^{3}\right)$ recommended by the National Institute of Occupational Safety and Health (NIOSH) and 25-50 times greater than the threshold level $\left(0.1 \mathrm{mg} / \mathrm{m}^{3}\right)$ recommended by the Occupational and Safety Health Association (OSHA) [12]. Inhaled silica particles usually lead to silicosis after 14 to 20 years duration of employment $[7,13]$ but in our stone-grinder workers the signs of silicosis appear after 5-7 years of employment, as shown by the significant difference in $\mathrm{FEV}_{\text {, }}$ FVC (for more than 10 years emp- loyment) and respiratory symptoms compared with the control group.

Stone-grinders are constantly exposed to different concentrations of crystalline silica, predisposing them to suffer benign pneumoconiosis, silicosis and tuberculosis. The characteristic pathogenesis begins with inhalation of silica particles and their deposition in alveolar spaces. Particles of diameter $<2 \mu \mathrm{m}$ and $>0.05 \mu \mathrm{m}$ have the best chance of entering and being retained in the pulmonary acini [14]. The key event in the genesis of pulmonary disease is the

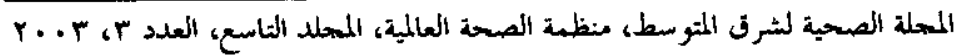


interaction between silica particles and alveolar macrophages [15].

Our main findings indicated that decreases in $\mathrm{FEV}_{1}, \mathrm{FVC}$ and $\mathrm{FVC} / \mathrm{PVC}$ across job groups was associated with concentrations of respirable dust in the ambient air and with duration of employment. Our findings are supported by other studies $[9,16-18]$. Ulvestad et al. reported that exposure to quartz in tunnel workers enhances the risk for accelerated decline in

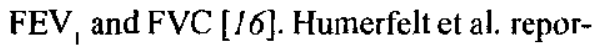
ted an inverse relationship between duration of quartz exposure and lung function (FVC and FEV, [9]. Forastiere et al. also reported that decreased $F V C$ and $F E V$, among ceramic workers in Italy was significantly associated with duration of exposure [17]. Hertzberg et al. calculated that there would be a decrease of $104.4 \mathrm{~mL}$ for $\mathrm{FEV}_{1}, 137.7 \mathrm{~mL}$ for FVC and $1.49 \%$ for FEV, $/ F V C$ after 40 years of exposure of silica at the Occupational Safety and Health Association (OSHA) exposure level of 0.1 $\mathrm{mg} / \mathrm{m}^{3}[18]$.

In our study the concentration of silica compounds in stone-grinding and ceramic factories were $25-50$ and $1-2$ times respectively higher than OSHA levels; therefore, a loss of FEV, FVC and FVC/PVC would be expected. Exposure to silica compounds at concentrations about 25-50 times more than the present total lung volume (TLV) was associated with airway obstruction and lost of elastic recoil rather than fibrosis. In pottery factories, workers were exposed to silica at levels less than the standard recommendation by OSHA, therefore, there were no significant differences in lung function tests for workers with less than 20 years employment. The results of the current study concerning the decrease of $\mathrm{FEV}$, and FVC in ceramic and FEV, pottery workers working for more than 20 years support the studies of Prowse et al. and Wang et al. $[4,19]$.
Prowse et al. also showed decreasing FEV , in pottery workers with increasing $\mathrm{X}$-ray category of silicosis irrespective of smoking habit [4]. We found a significant difference for $\mathrm{FEV}_{1}$ between stone-grinder workers and the control group among both smokers and non-smokers. Hertzberg et al. found the adverse effects of cigarette smoking in smokers exposed to silica at work would result in a $312 \mathrm{~mL}$ decrease of FEV, $232 \mathrm{~mL}$ of FVC and $3.4 \%$ of $\mathrm{FEV}_{\mathrm{i}} / \mathrm{FVC}$ [18]. Damage from smoking might make the lung tissue more vulnerable to other inhaled substances. Some studies reported the same results for smokers and others reported that obstructive changes among non-smokers occur in the presence of advanced silicosis [20,21]. Regarding the role of smoking in observed impairment of lung functions, we failed to measure any significant difference of lung functions (FVC, FEV , FEV,/FVC) among smokers and non-smokers working in stone-cutting and ceramic and pottery factories that may depend on concentrations of silica in ambient air.

According to some studies, lung function is a powerful predictor of morbidity $[22,23]$. Therefore the stone-grinder workers with a reduction of $\mathrm{FEV}_{1}$, and also workers of ceramic, pottery and stonecutting for more than 20 years, face an increased risk of death from respiratory disease. Early detection and treatment of respiratory ailments can help in reducing the associated mortality and morbidity.

\section{Conclusion}

The decline in pulmonary function $(\mathrm{FEV}$, FVC, FVC/PVC) of workers exposed to silica dust depends on the concentrations of respirable dust in the environment and the duration of employment. The processing of the stone has an important role in

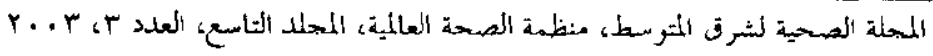


the emission of particles and using water during stone-cutting decreases the atmospheric concentrations of respiratory particles. The stone-grinder workers in this study in the Islamic Republic of Iran were at a risk of lung disease. Thus, we recommend that ventilation systems should be compulsory in the workplace of stonegrinders and that workers should reccive regular screening for lung disease.

\section{References}

1. De Clerk N. Silica compensated silicosis and lung cancer in Western Australian goldmines. Occupational and environmental medicine, 1998, 55(4):243-8.

2. Talini $D$ et al. Chest radiography and high resolution computed tomography in the evaluation of workers exposed to silica dust relation with functional findings. Occupational and environmental medicine, 1995 52(4):262-7.

3. Raymond DH. Hamilton \& Hardys industrial toxicology. Philadelphia, Mosby, 1998.

4. Prowse K, Allen MB, Bradbury SP. Respiratory symptoms and pulmonary impairment in male and female subjects with pottery workers silicosis. Annals of occupational hygiene, 1989, 33(3):37585.

5. Meijers JM, Swaen GM, Slangen JJ. Mortality and lung cancer in ceramic workers in the Netherlands: preliminary results. American journal of industrial medicine, 1996, 30:26-30.

6. Glover JR et al. Effects of exposure to slate dust in North Wales. British journal of industrial medicine, 1980, 37:152-62.

7. Encyclopedia of occupational health and safety. Geneva, Switzerland, International Labour Office, 1998.

8. Bagatin $E$ et al. Influence of exposure time to silica and smoking on pulmonary function of workers in the ceramic and stone quarry industry. [In Portugese].
AMB; revista da Associacao Medica Brasileira, 1991, 37:85-90.

9. Humerfelt S, Eide GE, Gulsvik A. Association of years of occupational quartz exposure with spirometric airflow limitation in Norwegian men aged 30-46 years. Thorax, 1998, 53:649-55.

10. Mannetji $A$ et al. Exposure-response analysis and risk assessment for silica and silicosis mortality in a pooled analysis of six cohorts. Occupational and environmental medicine, 2002, 59(11): 723-8.

11. Standardization of spirometry-1987 update. Statement of the American Thoracic Society. American review of respiratory disease, 1987, 136:1285-98.

12. Threshold limit values for chemical substances and physical agents biological exposure indices. Cincinnati, American Conference Governmental Industrial Hygiene, 2002.

13. Bingham $\mathrm{E}$, Cohrssen $\mathrm{B}$, Powell $\mathrm{CH}$, eds. Patty's toxicology. Volume 1. New York, Wiley, 2000.

14. Oberdorster $G$. Significance of particle parameters in the evaluation of exposure-dose-response relationships of inhaled particles. Inhalation toxicology, 1996, 8:73-89.

15. Erdogdu G, Hasirci V. An overview of the role of mineral solubility in silicosis and asbestosis. Environmental research, 1998, 78:38-42.

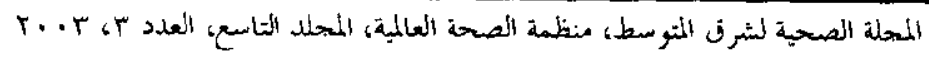


16. Ulvestad B et al. Increased risk of obstructive pulmonary disease in tunnel workers. Thorax, 2000, 55:277-82.

17. Forastiere $F$ et al. Silicosis and lung function decrements among female ceramic workers in Italy. American journal of epidemiology, 2002, 156(9):851-6.

18. Hertzberg VS et al. Effect of occupational silica exposure on pulmonary function. Chest, 2002, 122(2):721-8.

19. Wang $X$ et al. Respiratory impairment due to dust exposure: a comparative study among workers exposed to silica, asbestos, and coalmine dust. American journal of industrial medicine, 1997, 31(5):495-502.

20. Cowie HA et al. An epidemiological study of the respiratory health of workers in the European refractory ceramic fibre industry. Occupational and environmental medicine, 2001, 58:800-10.

21. Rego $G$ et at. The effects of dust inhalation in slate industry workers. [In Spanish]. Medicina clinica, 2001, 3(116): 290-1.

22. Vestbo J. Predictors of mortality, COPD morbidity and respiratory cancer with special reference to respiratory symptoms, lung function, and occupational exposure cement dust. Danish medicine bulletin, 1993, 40(1):1-16.

23. Sanden A, Jarvholm B, Larsson S. The importance of lung function, non-malignant disease associated with asbestos, and symptoms as predictors of ischaemic heart disease in shipyard worker exposed to asbestos. British journal of industrial medicine, 1993, 50(9):78590.

\section{Silicosis}

Sillcosis, one of the oldest occupational diseases, still kills thousands of people every year, everywhere in the world. It is an incurable lung disease caused by inhalation of dust containing free crystalline silica. It is irreversible and, moreover, the disease progresses even when exposure stops.

There is widespread lack of awareness of the problem and its magnitude as well as lack of knowledge of available solutions. The ILO/ WHO International Programme on the Global Elimination of Silicosls, launched In 1995, aims at the global reduction and eventual elimination of silicosis. It includes: the formulation of national, regional and global action plans; mobilization of resources for the application of primary and secondary prevention; epidemiological surveillance; monitoring and evaluation of results; and the strengthening of the required national capabilities and the establishment of national pro-
grammes. 